INTERNATIONAL JOURNAL OF RESEARCHES IN BIOSCIENCES, AGRICULTURE AND TECHNOLOGY (C) VISHWASHANTI MULTIPURPOSE SOCIETY (Global Peace Multipurpose Society) R. No. MH-659/13(N)

\title{
EFFECT OF SEED TREATMENT WITH INSECTICIDES AND FUNGICIDES ON GERMINATION AND SEEDLING DEVELOPMENT OF BHENDI
}

\author{
P. Lambat1, S. Charjan ${ }^{2}$, G. Mate ${ }^{2}$, M. Patil2, \\ A. Lambat $^{3}$, R. Gadewar ${ }^{3}$ and P. N. Charde ${ }^{2}$ \\ ${ }^{1}$ Shri Mathuradas Mohota Science College, Nagpur, M.S., India. \\ ${ }^{2}$ Sevadal Mahila Mahavidyalaya \& Research Academy, Nagpur, M.S., India. \\ ${ }^{3}$ Dr. P D K V'S College of Agriculture, Nagpur, M.S., India.
}

\begin{abstract}
:
The germination percentage and growth measurements of radicle and plumule fourteen days after seed treatment with four insecticides and fungicides singly and in combination with each other, were recorded for bhendi seeds. The germination percentage was affected greatly at middle and higher concentration of dimethoate and methyl demeton and higher concentrations of phosphamidon and monocrotophos. Lower and middle concentrations of phosphamidon and monocrotophos are safer as seed dressers to bhendi as they showed better germination followed by improved length of radicle and plumule. None of the fungicides had any adverse effect on the germination, radicle and plumular growth.
\end{abstract}

Keywords: Bhendi, insecticides, fungicides, germination, radicle, plumule.

\section{Introduction:}

Seed treatment with systemic insecticides is one of the most promising and economic methods of protecting the crops, especially in the early stages of their growth from the attack of different pests (Upadhyay and Mathur, 1984). Similar treatment with fungicides is also reported to control external and internal seed borne pathogens (Padmini Nagraj and Mallikarjunardhya (1985) and Mukewar (1990). Hussain (1978) and Nayeem (1979) reported phytotonic effect in greengram and maize respectively, when the seed was treated with carbofuran.

In the present study effect of seed treatment on Bhendi germination and seedling development with four insecticides and fungicides was studied individually and in combination.

\section{Materials and Methods}

Seeds of Bhendi CV. Pusa Savni and Parbhani Kranti produced in 1988, were treated with the commercial formulations of four insecticides, viz., dimethoate, phosphamidon, monocrotophos and methyldemeton at concentrations of 1,2 and $3 \%$ of active ingredient by weight of seed. The fungicides $\mathrm{v} / z$., carbendazim, captan, captafol and thiram were treated at $0.1,0.2$ and $0.3 \%$ concentrations. The procedure for seed dressing followed was per recommendations of the plant protection schedule (Anon, 1977).

The germination medium used was rolled towel paper (BP) and control condition (i.e., temperature $20^{\circ} \mathrm{C}$ constant and relative humidity $85 \%$ ). Germination was tested in quadruplicate with 100 seeds each replication. The final count was taken on the 14th day and germination percentage was recorded according to International rules for seed testing (Anon, 1985). For recording length measurement of plumule and radicle, ten seedlings from each treatment were selected randomly. The length of the same were recorded on the $14^{\text {th }}$ day and average value was determined.

\section{Results and Discussion}

\section{Effect of chemicals on germination of Bhendi} seeds:

As seen from (table 1) germination was affected by middle $(2 \%)$ and higher $(3 \%)$ concentrations of dimethoate and methyl demeton, respectively higher $(3 \%)$ concentration of phosphamidon and monocrotophos. Our results are mostly in agreement with those of Charjan and Tarar (1991).

The four fungicides viz., carbendazim, captan, captafol and thiram had on any adverse effect on the germination. The data revealed that all concentrations of fungicides accelerated the germination. The results reported here are in conformity with the observations made by earlier workers [Narsimhulu and Rao, 1989; Joi and Singh, 1990 and Charjan and Tarar, 1991. The germination percentage in the combination treatments increase as compared to control.

\section{Effect on radicle and plumule growth:}

The lower $(1 \%)$ and middle $(2 \%)$ concentrations of phosphamidon and monocrotophos was found to accelerate the radicle and plumular growth. The increase in radicle and plumule length may be due to some phytotonic effect Nayeem (1979) in case of maize and Hussain (1978) in case of green gram also reported similar effect of carbofuran. Dimethoate and methyl demeton showed adverse effect on the radicle and plumular growth in all concentrations. Cullinan (1949) reported injury to root system of the plant due to DDT, BHC, toxaphene and Chlorodane etc. This observation tallied well with that of Charjan and Tarar (1991).

In all the concentrations of fungicides tested, radicle and plumular growth was significantly increased against control. The results reported here are in conformity with the observations 
made by earlier workers Datar and Malale (1990). In combination treatment the chemical showed adverse effect on radicle and plumular growth except monocrotophos with four fungicides.

As the above mentioned lower and middle eon centrations of phosphamidon and monocrotophos respectively and all the concentrations of fungicides promoted the germination, radicle and plumular growth. Dimethoate and methyl demeton at lower $(1 \%)$ concentration accelerate the germination but adverse effect on radicle and plumular growth. Middle $(2 \%)$ and higher $(3 \%)$ concentration of same insecticides is highly phytotox and affected germination drastically suppressed the growth of radicle and plumule.

Hence phosphamidon and monocrotophos at $1 \%$ or $2 \%$ and fcarbendazim, (captan, icaptafol, and thiram at $0.3 \%$ are safer seed dressers to bhendi.

Table-1. Germination percentage and growth of plumule and radicle recorded on $14^{\text {th }}$ day in bhendi cultivars seeds treated with insecticides and fungicides.

\begin{tabular}{|c|c|c|c|c|c|c|c|}
\hline \multirow{2}{*}{$\begin{array}{l}\text { Treatment } \\
\text { and } \\
\text { Concentration }\end{array}$} & & \multicolumn{3}{|l|}{ Pusa Savni } & \multicolumn{3}{|c|}{ Parbhani Kranti } \\
\hline & & $\begin{array}{l}\text { Mean } \\
\text { Germination } \\
(\%)\end{array}$ & \begin{tabular}{|l} 
Mean \\
growth \\
on \\
radical \\
(cms)
\end{tabular} & $\begin{array}{l}\text { Mean } \\
\text { growth } \\
\text { on } \\
\text { plumule } \\
\text { (cms) }\end{array}$ & $\begin{array}{l}\text { Mean } \\
\text { Germination } \\
(\%)\end{array}$ & $\begin{array}{l}\text { Mean } \\
\text { growth } \\
\text { on } \\
\text { radical } \\
\text { (cms) }\end{array}$ & \begin{tabular}{|l|} 
Mean \\
growth on \\
plumule \\
(cms)
\end{tabular} \\
\hline Control & & 98.00 & 11.03 & 9.61 & 85.00 & 10.39 & 9.81 \\
\hline \multirow[t]{3}{*}{ Dimethoate } & $1 \%$ & 99.00 & 10.84 & 9.45 & 88.00 & 10.04 & 9.92 \\
\hline & $2 \%$ & 96.00 & 10.27 & 9.12 & 82.00 & 9.71 & 9.23 \\
\hline & $3 \%$ & 93.00 & 9.12 & 8.94 & 75.00 & 9.23 & 8.20 \\
\hline \multirow{3}{*}{ Phosphamidon } & $1 \%$ & 100.00 & 11.12 & 9.62 & 86.00 & 10.44 & 9.84 \\
\hline & $2 \%$ & 100.00 & 11.84 & 10.41 & 90.00 & 11.12 & 10.42 \\
\hline & $3 \%$ & 96.00 & 10.84 & 8.74 & 81.00 & 10.31 & 9.13 \\
\hline \multirow[t]{3}{*}{ Monocrotophos } & $1 \%$ & 100.00 & 11.42 & 9.92 & 88.00 & 10.82 & 10.12 \\
\hline & $2 \%$ & 100.00 & 12.16 & 10.13 & 93.00 & 11.12 & 10.84 \\
\hline & $3 \%$ & 97.00 & 10.86 & 9.42 & 88.00 & 11.19 & 10.92 \\
\hline \multirow{3}{*}{$\begin{array}{l}\text { Methyl } \\
\text { demeton }\end{array}$} & $1 \%$ & 99.00 & 10.80 & 9.42 & 87.00 & 10.22 & 9.44 \\
\hline & $2 \%$ & 95.00 & 10.62 & 9.16 & 81.00 & 9.74 & 8.82 \\
\hline & $3 \%$ & 92.00 & 9.71 & 8.81 & 79.00 & 9.12 & 8.04 \\
\hline \multirow[t]{3}{*}{ Carbendazim } & $0.1 \%$ & 98.00 & 12.12 & 9.92 & 89.00 & 11.42 & 10.12 \\
\hline & $0.2 \%$ & 100.00 & 13.64 & 10.12 & 92.00 & 12.12 & 10.94 \\
\hline & $0.3 \%$ & 100.00 & 13.96 & 11.43 & 96.00 & 14.02 & 11.76 \\
\hline \multirow[t]{3}{*}{ Captan } & $0.1 \%$ & 99.00 & 12.42 & 9.67 & 88.00 & 11.47 & 10.04 \\
\hline & $0.2 \%$ & 100.00 & 13.53 & 10.31 & 91.00 & 12.42 & 11.06 \\
\hline & $0.3 \%$ & 100.00 & 14.16 & 11.86 & 97.00 & 14.12 & 11.92 \\
\hline \multirow{3}{*}{ Captafol } & $0.1 \%$ & 98.00 & 11.64 & 9.77 & 89.00 & 10.84 & 9.92 \\
\hline & $0.2 \%$ & 99.00 & 12.16 & 9.98 & 92.00 & 12.14 & 10.72 \\
\hline & $0.3 \%$ & 99.00 & 13.84 & 10.92 & 94.00 & 13.69 & 11.19 \\
\hline \multirow[t]{3}{*}{ Thiram } & $0.1 \%$ & 100.00 & 12.64 & 10.73 & 90.00 & 11.12 & 10.82 \\
\hline & $0.2 \%$ & 100.00 & 13.49 & 11.79 & 94.00 & 12.46 & 11.42 \\
\hline & $0.3 \%$ & 100.00 & 14.42 & 12.16 & 98.00 & 14.26 & 12.04 \\
\hline Dimethoate & $1 \%$ & & & & & & \\
\hline+ & & 100.00 & 10.94 & 9.42 & 95.00 & 10.52 & 9.72 \\
\hline Carbendazim & $0.3 \%$ & & & & & & \\
\hline Dimethoate & $1 \%$ & & & & & & \\
\hline+ & & 100.00 & 10.82 & 9.54 & 97.00 & 10.42 & 9.61 \\
\hline Captan & $0.3 \%$ & & & & & & \\
\hline Dimethoate & $1 \%$ & & & & & & \\
\hline+ & & 98.00 & 10.69 & 9.49 & 94.00 & 10.32 & 9.41 \\
\hline Captafol & $0.3 \%$ & & & & & & \\
\hline Dimethoate & $1 \%$ & & & & & & \\
\hline+ & & 100.00 & 10.91 & 9.54 & 99.00 & 10.59 & 9.54 \\
\hline Thiram & $0.3 \%$ & & & & & & \\
\hline Phosphamidon & $1 \%$ & & & & & & \\
\hline+ & & 100.00 & 11.01 & 9.49 & 97.00 & 10.22 & 9.72 \\
\hline Carbendazim & $0.3 \%$ & & & & & & \\
\hline Phosphamidon & $1 \%$ & & & & & & \\
\hline+ & & 100.00 & 10.94 & 9.52 & 96.00 & 10.49 & 9.62 \\
\hline Captan & $0.3 \%$ & & & & & & \\
\hline
\end{tabular}




\begin{tabular}{|c|c|c|c|c|c|c|c|}
\hline Phosphamidon & $1 \%$ & & & & & & \\
\hline+ & & 99.00 & 10.79 & 9.42 & 96.00 & 10.32 & 9.32 \\
\hline Captafol & $0.3 \%$ & & & & & & \\
\hline Phosphamidon & $1 \%$ & & & & & & \\
\hline+ & & 100.00 & 10.84 & 9.41 & 98.00 & 10.56 & 9.49 \\
\hline Thiram & $0.3 \%$ & & & & & & \\
\hline Monocrotophos & $1 \%$ & & & & & & \\
\hline+ & & 100.00 & 12.56 & 10.82 & 96.00 & 10.61 & 9.89 \\
\hline Carbendazim & $0.3 \%$ & & & & & & \\
\hline Monocrotophos & $1 \%$ & & & & & & \\
\hline+ & & 100.00 & 12.64 & 10.92 & 98.00 & 10.52 & 9.92 \\
\hline Captan & $0.3 \%$ & & & & & & \\
\hline Monocrotophos & $1 \%$ & & & & & & \\
\hline+ & & 100.00 & 12.12 & 10.81 & 97.00 & 10.41 & 9.71 \\
\hline Captafol & $0.3 \%$ & & & & & & \\
\hline Monocrotophos & $1 \%$ & & & & & & \\
\hline+ & & 100.00 & 12.60 & 10.78 & 98.00 & 10.69 & 9.96 \\
\hline Thiram & $0.3 \%$ & & & & & & \\
\hline Methyldemeton & $1 \%$ & & & & & & \\
\hline+ & & 99.00 & 10.82 & 9.42 & 95.00 & 10.12 & 9.42 \\
\hline Carbendazim & $0.3 \%$ & & & & & & \\
\hline Methyldemeton & $1 \%$ & & & & & & \\
\hline+ & & 100.00 & 10.49 & 9.34 & 97.00 & 10.22 & 9.39 \\
\hline Captan & $0.3 \%$ & & & & & & \\
\hline Methyldemeton & $1 \%$ & & & & & & \\
\hline+ & & 98.00 & 10.52 & 9.19 & 94.00 & 10.04 & 9.12 \\
\hline Captafol & $0.3 \%$ & & & & & & \\
\hline Methyldemeton & $1 \%$ & & & & & & \\
\hline+ & & 100.00 & 10.42 & 9.49 & 96.00 & 10.24 & 9.29 \\
\hline Thiram & $0.3 \%$ & & & & & & \\
\hline
\end{tabular}

\section{References:}

Anonymonus, 1977. Plant Protection Schedule, Department of Agriculture, Maharashtra State, Pune.

Anonymous, 1985. International rules for seed testing. Seed Sci. And Technol.3:299-513.

Cullinan, P.P., 1949. Some new insecticides their effects on plants and soils. J. Econ. Ent., 42 : 387-391.

Charjan, S.K.U. and Tarar, J.L, 1991. Effect of systemic insecticides and fungicides seed treatment on the germination and seedling development of soybean (Glycine max L.). Paper presented at the 78th Session on the Indian Science Congress, held at Indore, 1991.

Datar, V.V. and Malale, V.B., 1990. Efficacy of different seed dresser fungicides on Colletotrichum capsicionchilli Paper presented at the International Conf. on Seed Sci. and Technol., held at New Delhi from Feb. 211-25. 1990.

Hussain, M.Y. B., 1978. Soil application of granules of carbofuran to control beanfly ophiomyia phaseoli (Tryon). Partanika, 1(1) : 3639.

Joi, NLB. and Singh, Y.S., 1990. Detection of seed- borne fungi from cruciferous vegetables and their control. Paper presented at the
International Conference on Seed Sci. and Technol. held at New Delhi from Feb. 21-25, 1990.

Mukewar, P.M., 1990. Present status of seed borne diseases of cotton in India and the application of seed treatments. Paper presented at the International Conf. On Sefed Sci. and Technol., held a New Delhi from Feb. 2125.1990 .

Nayeem, H.A., 1979. Growth promoting effect of carbofuran Sorghum Bicolor L. Moench., Maharashtra Agril. University., 4(1): 119-120.

Narasimhulu, T. and Rao. K.P., 1989. Effect of seed treatment with insecticides and fungicides on germination of peanut seed. Seed Res., 17(2): 159-163

Padmini Nagraj) and Mallikarjunardhya, S., 1989. In vitro evaluation of some fungicides against groundnut seed mycoflora. Pesticides, 19(8): 51-52.

Upadhyay. K.D. and Mathur, Y.K., 1984. A new dimension in control of white grub Holotrichia Consanquinea Blanch.) by seed treatment, Pesticides, 28(9): 21-22. 